\title{
Economic, social, energy and environmental assessment of inter-municipality commuting: The case of Portugal
}

\author{
João-Pedro Ferreira*, Eduardo Barata, Pedro Nogueira Ramos, Luis Cruz \\ GEMF, Faculty of Economics, University of Coimbra, Av. Dias da Silva 165, 3004-512 Coimbra, Portugal
}

\section{H I G H L I G H T S}

- This paper provides an insight into the magnitude of opportunity costs of commuting.

- Input-output modeling is valuable to assess changes in final consumption patterns.

- About $25 \%$ of household's fuel consumption is due to inter-municipality commuting.

- Inter-municipality commuting has net negative effects on GDP, GVA and employment.

- The main opportunity costs come from metropolitan and long distance commuting.

\section{A R T I C L E I N F O}

\section{Article history:}

Received 20 March 2013

Received in revised form 1 November 2013

Accepted 6 November 2013

Keywords:

Commuting

Input-output analysis

Impact assessment

\begin{abstract}
A B S T R A C T
Commuting is one of the main contributors to the high energy consumption patterns in modern economies. The need to reduce the energy spent in commuting has attracted the attention of academics and policy makers. The main goal of this research is to improve knowledge of the economic, social, energy and environmental opportunity costs of inter-municipality commuting and to support policyoriented strategies that explicitly take them into account. For this, we use hypothetical assumptions based on the baseline scenario that Portuguese households do not travel between municipalities for commuting purposes coupled with the expected changes in private final consumption. Accordingly, the direct, indirect and induced opportunity costs of inter-municipality commuting are assessed using an input-output model. The significance of the estimated virtual net benefits of commuting is analyzed according to their macroeconomic (GVA, taxes, international imports and employment), energy (primary energy consumption) and environmental $\left(\mathrm{CO}_{2}\right.$ emissions) dimensions. The results obtained empirically indicate that inter-municipality commuting has significant opportunity costs in the GVA and GDP as well as in primary energy consumption and $\mathrm{CO}_{2}$ emissions. The results also indicate that commuters in metropolitan regions and long-distance commuters are responsible for a major share of these opportunity costs.
\end{abstract}

(c) 2013 Elsevier Ltd. All rights reserved.

\section{Introduction}

The urban population has grown consistently throughout the last century, worldwide. Large metropolitan areas have expanded in terms of population and dimension. Naturally, these processes did not occur homogeneously. Over recent decades, the population in the suburbs of most European and American cities has tended to increase while the population living in Central Business Districts has generally shrunk. Portugal was no exception. Census data shows that between 1980 and 2011 Lisbon and Porto

\footnotetext{
* Corresponding author. Tel.: +351 239790 500; fax: +351239790 514 .

E-mail addresses: joao.ferreira@fe.uc.pt, joao.pr.ferreira@gmail.com (J.-P. Ferreira), ebarata@fe.uc.pt (E. Barata), pnramos@fe.uc.pt (P.N. Ramos), lmgcruz@fe.uc.pt (L. Cruz).
}

municipalities lost $33 \%$ and $27 \%$ of their population, respectively. But the population of Greater Lisbon and Greater Porto metropolitan areas has increased by more than $14 \%$ and $15 \%$, respectively (INE, 2012). This phenomenon is often referred to as urban sprawl and is associated with an increasing need to travel further between home and workplace. This increase in commuting was sustained by economic conditions that enabled people to buy fuel at relatively low prices. Such conditions have favored increases in the consumption of primary energy and consequently in $\mathrm{CO}_{2}$ emissions.

Analyzing the Portuguese consumption of Refined petroleum products in 2007 , we can see that $21.5 \%$ is due to household consumption, $23.2 \%$ is for exportation and the rest is consumed as intermediate goods for industrial production. Additionally, $7.5 \%$ of total household income is spent on buying and repairing cars and 
$1.4 \%$ on road and rail passenger transportation services (INE, 2011). Consumption of these products affects the consumption of natural resources and the generation of pollutants as well as the corresponding levels of gross domestic product (GDP), gross value added (GVA), employment, imports and tax collection. In the Portuguese economy (and other European economies), these goods are mainly imported or require a large amount of imported inputs in their production processes, thereby contributing to the negative impacts on the balance of payments and to reducing the multiplier effects in the economy.

This research contributes to improving knowledge on the economic, social, energy and environmental opportunity costs of inter-municipality commuting ${ }^{1}$. These aspects of commuting are addressed by analyzing different scenarios. The first scenario addresses the likely impacts of ceasing metropolitan versus nonmetropolitan commuting. In this case, attention is focused on the trips made by commuters within the two major Portuguese metropolitan areas: Lisbon and Porto. The second scenario distinguishes between the energy and economic impacts of short and long distance commuting. The definition of short and long commute is related to the estimation of average trip-distance per commuter. Finally, to evaluate the overall opportunity costs of commuting, a very extreme scenario takes the reference assumption that all the inter-municipality commuting in Portugal ceases, i.e. that people work in the same municipality in which they live or, alternatively, for our modeling purposes, any commuting to other municipalities does not involve fossil energy or other commuting expenditure. Accordingly, the opportunity costs of commuting can be estimated as the differences between the current situation (2007, our base year) and the suggested scenarios. It is important to note that in the scenarios in which no intermunicipality commuting is assumed, the consumption of Portuguese households in terms of cars, fuel and other products is reduced and, conversely, their spending on other products unrelated to commuting is increased. We assessed the economic, social, energy and environmental effects of commuting, by applying an input-output (I/O) model with a supply and use table (SUT) format at basic prices and domestic flows, extended with an energy-environment satellite account. The results consider different energy and environmental indicators (oil, natural gas, coal consumption and $\mathrm{CO}_{2}$ emissions) as well as economic and social ones (GDP, GVA, imports, VAT, other taxes on products and employment).

This modeling approach provides important insights for policy makers, in particular by contributing to a better understanding of where commuting policies can be more effective and which categories of commuting have higher opportunity costs. Several strategies regarding the demand and supply of transportation, the price and taxes paid by car owners and by fuel consumers, and even differentiated urban taxes can be proposed to induce a reduction in the vehicle miles traveled and in the number of commuters within a metropolitan area.

The next section contains a concise literature review, highlighting the leading attempts to address the impacts of commuting on the economy, environment and energy consumption. The instruments that can be used to achieve more sustainable commuting patterns are also discussed since this would make a significant contribution to cutting energy consumption and thus to reducing the commuting footprint. Section 3 presents the methodology, i.e. the procedures to estimate fuel consumption

${ }^{1}$ It should be taken into account that inter-municipality commuting is only a share, expected to be significant, of overall commuting. Our option to focus on this type of commuting also took into account the absence of data on intra-municipality commuting, i.e. Portuguese Census data only identify the origin and destiny of commuters when they travel between municipalities. associated with inter-municipality commuting scenarios, the approach to assessing the impact on the other products in the economy and, finally, a brief description of the I/O model adopted and the derivation of the energy-environment satellite account. Section 4 gives the results obtained and suggests opportunities to explore the policy significance of the energy, environmental, economic and social opportunity costs associated with intermunicipality commuting.

\section{Literature review}

In recent years, people have become increasingly aware of critical issues such as energy consumption and greenhouse gas (GHG) emissions. Accordingly, numerous contributions have focused their attention on the issue of passenger transportation, stressing its responsibility for $20 \%$ of the world primary energy use and in $13 \%$ of energy-related $\mathrm{CO}_{2}$ emissions (IEA, 2006; Zhao et al., 2011). Regarding the Portuguese case, it is worth mentioning that in 2010 the transportation sector's total share of final energy consumption was $40.6 \%$, while this sector's direct 'responsibility' for GHG emissions reached a share of 26.8\% (EUROSTAT, 2013). These figures, especially regarding passenger transportation, have to a large extent been related to urban forms and city density, i.e., as the constraints on traveling greater distances have been relaxed, cities have expanded and become less dense. This led to a fast increase in car ownership and use (Glaeser and Kahn, 2001; Zhao et al., 2011). For example, Camagni et al. (2002), in a study on the Milan metropolitan area, confirmed that higher energy consumption and environmental impacts are associated with lower density, sprawling development and urbanization. Modarres (2013) confirms the importance of urban density in determining commuting patterns and therefore on related energy consumption. These studies, and others focusing more on energy consumption or its environmental consequences (Naess et al., 1995; Naess, 2010) had come to similar conclusions regarding the effects of extensive car use, the modal split and energy consumption. Fu et al. (2012) estimated the energy savings per commuter in Ireland, resulting from the increase in home working. Banister et al. (1997) and Muñiz and Galindo (2005) highlight that energy consumption is also related to travel distance, transport mode choice and journey frequency. Overall, these authors argue that policies to restrain commuting should have top priority in terms of energy and emissions reduction.

To promote the modal split within a metropolitan area, transportation demand management (TDM) policies are being applied with the aim of influencing people's travel behavior in such a way that alternative mobility options are presented and/or congestion is reduced (Meyer, 1997). Meyer (1999) explores 3 different sets of strategies: (a) alternative transportation choices; (b) (dis)incentives to reduce traveling, and (c) satisfaction of the trip's purpose by other, non-transportation means. Murray (2001) argues that one critical challenge for urban planners and decisionmakers is to identify effective strategies for dealing with resistance to travel by public transport. Some of the instruments used include reducing the price of public transit (Dorsey, 2005), subsidizing public transport in order to increase feasibility (Tisato, 1998) and improving the information available to users and/or on the network coverage (Litman, 2011). In many cities, parking fees are also being charged, mainly to rebalance the modal split between private car and alternative public transit systems (D'Acierno et al., 2006; Barata et al., 2011). Congestion tolls to enter the central business district, restrictions on the issuance of car license plates by a period of time, and the circulation of vehicles depending on the license plates are also good examples of additional TDM instruments that have been considered by metropolitan area 
authorities all over the world. The contribution of these arrangements to mitigate the significant environmental impacts of commuting has also been invoked to justify the application of regulatory instruments aimed at the direct reduction of GHG emissions. namely Ou et al. (2010) and Balat and Balat (2009), in particular, assess the effects of promoting alternative fuels or vehicles, while Offer et al. (2010) and Thiel et al. (2010) examine different scenarios regarding the introduction of innovative types of vehicles. Overall, the dominant strategy confronts the need to reduce travel activity and involves, increasing, directly or indirectly the relative price borne by car users within the metropolitan area.

The ambition to design policies capable of controlling the travel activity is also associated with approaches that take into account the spatial distribution of households and/or economic activities in a certain region. Frank and Pivo (1994) concluded that there is a statistical relationship between mode choice and land-use mix. Brueckner (2000) gives several hypothetical measures that could be adopted by American municipalities to control cities' expansion. The author justifies the need to implement these instruments by showing that the market has failed. Among his suggestions are: (a) charging a development tax on each acre of land converted from agricultural to urban use; (b) the implementation of TDM strategies that could reduce road usage to socially optimal levels, and/or (c) changing the system of infrastructure financing so that suburban inhabitants would be expected to pay for the social infrastructure costs arising from their decision to migrate to the periphery. More recently, Susilo and Stead (2007) claim that if one classifies individuals according to the degree of urbanization of the home's municipality, based on the metropolitan density, it would be possible to discern distinct trends of travel behavior, transport energy use and emissions.

However, none of the above contributions deals with internalizing the economic interdependencies which characterize each economy within a certain geographical area. For example, it is important to be aware that if a given economy modifies the consumption of a certain electricity-intensive product, the corresponding macroeconomic and environmental shocks will depend of the type of inputs used in electricity production or in the origin of the electricity (domestic or from abroad).

The I/O models offer a method to properly integrate these economic interdependencies, especially if extended to deal with both energy and environmental issues (Cruz et al., 2005; Miller and Blair, 2009). These models can present the results in terms of direct impacts but they also give the chance to pinpoint the indirect and induced impacts of a real or simulated shock. For instance, if the automobile industry increases its production the energy consumed is expected to increase, this simultaneously leads to increases in the production of car components (indirect effects). Moreover, as production expands household income also increases, leading to a subsequent increase in the household's consumption (induced effects).

Cruz (2009), and Cruz and Barata (2011) developed satellite accounts in order to analyze the links between the different economic sectors, energy production and use, and the "corresponding' production of $\mathrm{CO}_{2}$ emissions. Regarding the focus on energy studies Alcántara and Roca (1995), Labandeira and Labeaga (2002) and Cardenete and Saguar (2011) have also employed an I/O model to estimate primary energy consumption and $\mathrm{CO}_{2}$ emissions. The potential to apply these models regionally or nationally critically depends on the possibility of splitting the emissions generated by the branches of the economy into different effects depending on the demands their outputs have to satisfy. Alcántara (2011) also applied I/ $\mathrm{O}$ techniques to analyze the different types of final demand and their importance in $\mathrm{CO}_{2}$ emissions in Spain. These models, which may include energy, waste or water and economic data, are mostly referred to as hybrid or extended I/O models.
The main idea of all these modeling approaches is that the energy consumption depends on the domestic production and therefore on the consumption by households and Government, either domestically or for export. Indeed, the idea of simulating the changes in households' consumption patterns within an $\mathrm{I} / \mathrm{O}$ modeling framework has been widely implemented. For instance, this methodology was used to estimate the potential economic impacts of a change in the diet of households in Flanders (Dils et al., 2012) or the economic and environmental consequences of providing electricity to rural areas of India (Shimpo et al., 2009). More recently, Berglund (2012) analyzed a time-series of $\mathrm{CO}_{2}$ emissions from 1993 to 2005 to estimate the global climate impact of the different consumption levels by Swedish households. In short, the I/O models have the potential to estimate the direct, indirect and induced impacts which result from external shocks in the economy or simply from changes in consumption patterns. Simultaneously, when dealing with hybrid I/O, the results often include the impacts related to primary energy consumption and $\mathrm{CO}_{2}$ emissions. In the next section we first describe the methodology used to estimate the change in Portuguese household consumption patterns associated with different scenarios regarding inter-municipality commuting. Second, we present our I/O hybrid model, as well as the estimations made in order to assess the direct, indirect and induced impacts on the Portuguese economy.

\section{Methodology}

In this section, the methodology used to estimate the economic, social, energy and environmental impacts of the different scenarios regarding inter-municipality commuting is described. This research set out to see how household final consumption patterns change as inter-municipality commuting tends to decline. Our approach is divided into three major steps. The first consists of estimating fuel consumption expenditure related to intermunicipality commuting, divided by metropolitan or nonmetropolitan regions and by long and short commuting. The second concerns the estimation of the different consumption patterns in households which commute intensively and others that do not. Finally, these data are incorporated in an extended I/O model to assess the direct, indirect and induced impacts that the cessation of inter-municipality commuting would generate in Portugal's economic, social, energy and environmental dimensions, i.e. the opportunity costs of current commuting patterns.

\subsection{Distance traveled and fuel consumption}

The first step is to estimate fuel consumption by Portuguese households arising from inter-municipality commuting. Data on the number of commuters between municipalities from the 2001 Census are used (INE, 2003). We find that about $23.7 \%$ of Portuguese individuals (who have started to work or study) have to travel daily to a different municipality. The information on the modal share in each municipality is considered next. Our purpose is to estimate the number of daily inter-municipality commuters who are car users. Then, using a matrix representing the kilometer road distance between Portuguese municipalities (Ferreira et al., 2012) we estimate that Portuguese commuters travel approximately $50 \times 10^{6}$ kilometers $(\mathrm{km})$ by car each day. $59 \%$ of the kilometers traveled in inter-municipality commuting are trips within the Portuguese metropolitan areas of Lisbon and Porto. In contrast, only $41 \%$ of the kilometers traveled by daily commuters are journeys outside metropolitan regions. These figures confirm that people commute more intensively within the metropolitan areas. An average trip distance of approximately $56 \mathrm{~km}$ per day was estimated for Portuguese commuters. For modeling purposes, 
in the scenario concerned with the distance traveled by commuters, a short commute is taken to be every trip shorter than the average trip distance and a long commute is any trip longer than that. Applying these procedures, we estimated that short commuting accounts for only $22 \%$ of the total fuel consumption associated with inter-municipality commuting, against $78 \%$ for long commuting.

To estimate the liters (L) of fuel consumed we have combined the methodology proposed by Carvalho et al. (2012) and data from the Portuguese Automobile Association (ACAP, 2009). The results show average consumptions of 7.1 and $6.7 \mathrm{~L} / 100 \mathrm{~km}$ for gasoline and diesel, respectively, in 2007. Accordingly, our estimates indicate that intermunicipal car commuters used more than $3 \times 10^{6} 1$ of fuel per day. Finally, using the 2007 average annual price per liter of fuel type (DGEG, 2012b), the daily expenditure in fuel is estimated and, taking the "Portuguese working days" in that year, we calculated that in 2007 households spent approximately $485 \times 10^{6}$ euros on gasoline and $362 \times 10^{6}$ euros on diesel with inter-municipal commuting. In the extreme scenario, these figures correspond to $25.2 \%$ and $24 \%$ of the accumulated spending on gasoline and diesel, respectively, by households where the head the household is less than 65 years old.

\subsection{Household consumption changes}

Commuting practices have further impacts on a household's final consumption than the direct consumption of Refined petroleum products, i.e. we should not forget that there are several other products whose consumption is affected by commuting. To study these phenomena we used the Portuguese Household Budget Survey, disaggregated by 199 products (INE, 2008). This survey does not contain explicit information on the commuting patterns of households. Thus, to analyze commuting behavior we divided our sample and estimated two different household consumption structures: one is the consumption pattern of commuting-intensive households, and the other is the rest. This was done using two criteria: the amount spent on fuel, and the expenditure on public transportation services.

Comparison of these two consumption structures revealed several differences in products related to transportation, insurance and spending in restaurants. Table 1 illustrates the changes considered for some products that were taken into account in this modeling exercise.

The changes in these products' final consumption and the reduction in fuel consumption represented a total reduction of approximately $2.7 \%$ of a household's final consumption. For our modeling purposes, in order to offset this household's consumption of the other products was increased assuming a stable overall marginal propensity to consume (and therefore the marginal propensity to save).

Table 1

Changes in households' final consumption (for the scenario with no intermunicipality commuting)

\begin{tabular}{|c|c|}
\hline Product & $\begin{array}{l}\text { Change in final } \\
\text { consumption (\%) }\end{array}$ \\
\hline Manufacture of motor vehicles & -16.0 \\
\hline $\begin{array}{l}\text { Wholesale, Retail trade and Repair of motor vehicles } \\
\text { and motorcycles }\end{array}$ & -25.1 \\
\hline Interurban passenger transport by rail & -9.5 \\
\hline Other passenger land transport (urban) ${ }^{\mathrm{a}}$ & +21.2 \\
\hline $\begin{array}{l}\text { Warehousing and support activities for } \\
\text { transportation }\end{array}$ & -24.8 \\
\hline Food and beverage service activities (in restaurants) & -7.7 \\
\hline Non-life insurance & -9.6 \\
\hline
\end{tabular}

a This value is positive due to the increase in the use of urban public transportation within metropolitan areas.

\subsection{Input-output model}

The assessment of the differences in final household consumption resulting from a change in the commuting patterns is the first step to identifying the direct, indirect and induced impacts that would occur under the extreme scenario of no inter-municipality commuting. Our approach is based on an I/O table, whose structure is presented in Fig. 1. It has 431 products and 125 sectors, at domestic flows and basic prices, and its starting point is the Portuguese National Accounts Supply and Use Table (SUT), for the year 2007 (INE, 2011). An important feature of this $\mathrm{I} / \mathrm{O}$ table is the consideration of two household groups: those headed by a person over 65 years old, and those headed by a person less than 65 years old ${ }^{2}$. In the modeling procedure we have assumed that only those under 65 would be in a condition to commute to their school or workplace. In order to include the induced impacts, the $\mathrm{I} / \mathrm{O}$ table was 'closed' to the consumption of this latter household group. The consumption by 'over 65 ' households was considered in the exogenous part of the matrix. More details on these modeling procedures may be found in Ramos et al. (2011). Additionally, using a satellite account approach for primary energy consumption by industry (DGEG, 2012a), the changes in oil, natural gas and coal consumption are evaluated in terms of tons of oil equivalent (toe). Then the corresponding $\mathrm{CO}_{2}$ emissions are calculated, using the conversion units for each type of fuel suggested by the Intergovernmental Panel on Climate Change (IPCC, 2006; IA, 2011). The methodology used for these calculations as that described in Cruz (2009).

Let us call the large matrix of Fig. 1 'A', composed of $\mathbf{Z}, \mathbf{P}$ and the 0 filled quadrants. Let us call the vector comprising $\mathbf{X}^{\mathbf{P}}$ and $\mathbf{X}^{\mathbf{I}} \mathbf{X}$ '. From Fig. 1 it can be seen that:

\section{$\mathbf{A} . \mathbf{i}+\mathbf{Y} . \mathbf{i}=\mathbf{x}$}

where $\mathbf{i}$ denotes 1-filled column vectors, of appropriate size, whose mission is to add up the different columns of $\mathbf{A}$ and $\mathbf{Y}$. We can also compute input coefficients in matrix $\mathbf{A}$, dividing each of its cells by the entries in $\mathbf{x}^{\mathbf{P}^{\prime}}$ and $\mathbf{x}^{\mathbf{I}^{\prime}}$ located at the bottom of Fig. 1 (being the totals of the corresponding columns).

$b_{i j}=z_{i j} / x_{j}^{I}$ and $q_{i j}=p_{i j} / x_{j}^{P}$ are the two different sets of input coefficients representing the locally produced inputs (at basic prices) used in the production processes of industries and the shares of each industry in the production of each product (as principal or secondary products), respectively. $\mathbf{C}$, the input coefficients matrix, may be defined as

$$
\mathbf{C}=\left[\begin{array}{c|c} 
& \mathbf{B} \\
\mathbf{0} & \left(b_{i j}\right) \\
\hdashline \mathbf{Q} & \mathbf{0}
\end{array}\right]
$$

Thus, we can rewrite Eq. (1) as

$$
\mathbf{C .} \mathbf{X}+\mathbf{y}=\mathbf{x}(\mathbf{y} \text { is the vector } \mathbf{Y} . \mathbf{i})
$$

so

$\mathbf{X}=(\mathbf{I}-\mathbf{C})^{-1} \cdot \mathbf{y}$

The multipliers matrix $\mathbf{D}=(\mathbf{I}-\mathbf{C})^{-1}$ in fact has four parts:

$$
\mathbf{D}=\left[\begin{array}{c|c}
\mathbf{D}^{1} & \mathbf{D}^{2} \\
\hdashline \mathbf{D}^{3} & \mathbf{D}^{4}
\end{array}\right]
$$

$\mathbf{D}^{1}$ and $\mathbf{D}^{3}$ respectively represent the impacts on product outputs and industry outputs of changes in exogenous final demand, condensed in $\mathbf{y} . \mathbf{D}^{2}$. $\mathbf{D}^{4}$ are multipliers that measure the effects on $\mathbf{x}^{\mathbf{P}}$ and $\mathbf{X}^{\mathbf{I}}$ as well, of a reallocation of the final demand to the industries that

\footnotetext{
${ }^{2}$ This model was developed under research project DEMOSPIN (FCT PTDC/CS DEM/100530/2008), in which the authors participate.
} 

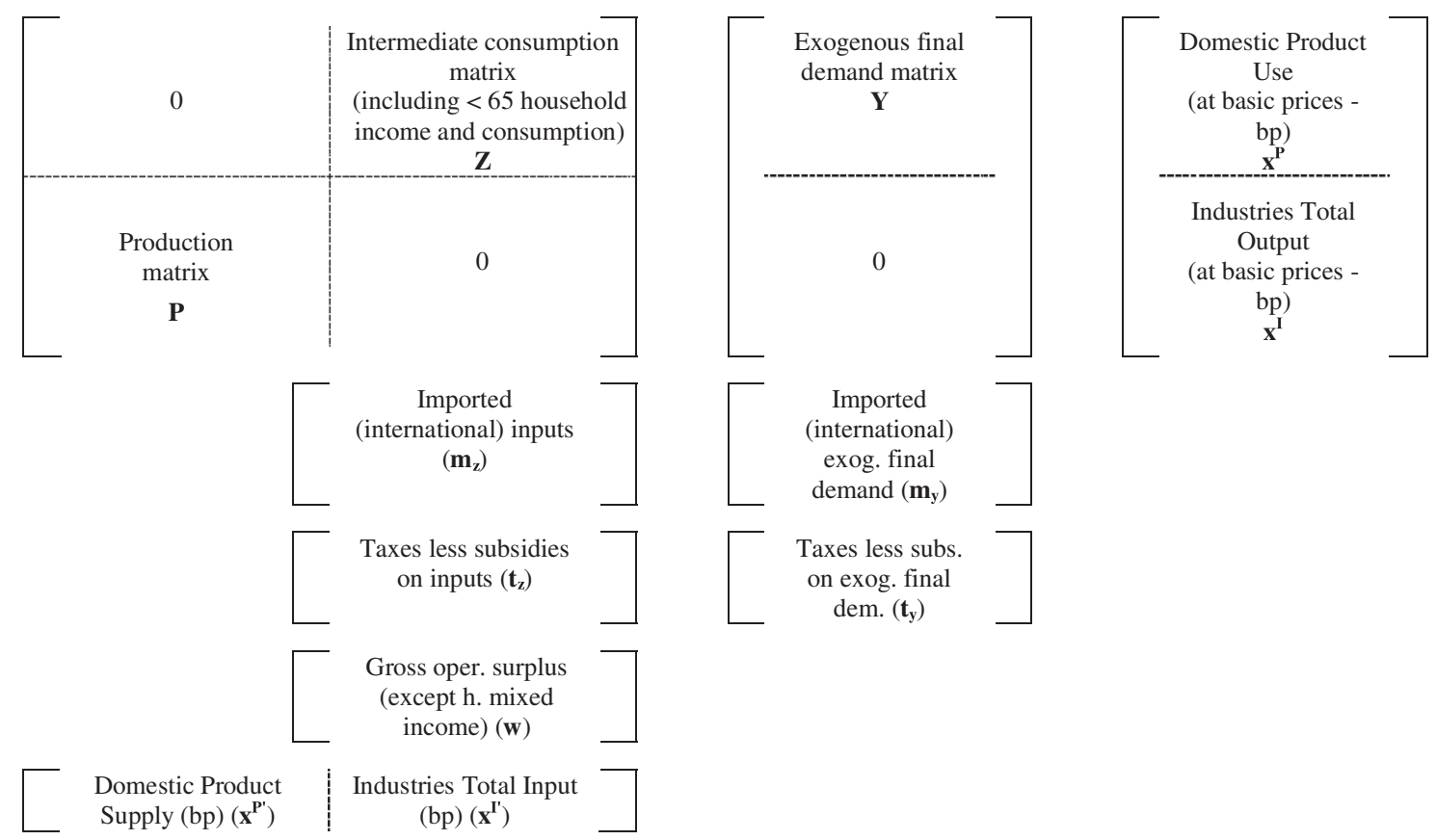

Fig. 1. General framework of the $\mathrm{I} / \mathrm{O}$ table.

Table 2

Distance per day and number of commuters.

\begin{tabular}{|c|c|c|c|c|c|c|c|c|c|c|}
\hline & \multicolumn{4}{|c|}{ Scenario 1} & \multicolumn{4}{|c|}{ Scenario 2} & \multicolumn{2}{|c|}{ Extreme scenario } \\
\hline & \multicolumn{2}{|c|}{ Metropolitan } & \multicolumn{2}{|c|}{ Non-metropolitan } & \multicolumn{2}{|l|}{ Short } & \multicolumn{2}{|l|}{ Long } & & \\
\hline & $\begin{array}{l}\text { Absolute } \\
\text { value }\end{array}$ & $\begin{array}{l}\% \text { of the } \\
\text { total }\end{array}$ & $\begin{array}{l}\text { Absolute } \\
\text { value }\end{array}$ & $\begin{array}{l}\% \text { of the } \\
\text { total }\end{array}$ & $\begin{array}{l}\text { Absolute } \\
\text { value }\end{array}$ & $\begin{array}{l}\% \text { of the } \\
\text { total }\end{array}$ & $\begin{array}{l}\text { Absolute } \\
\text { value }\end{array}$ & $\begin{array}{l}\% \text { of the } \\
\text { total }\end{array}$ & $\begin{array}{l}\text { Absolute } \\
\text { value }\end{array}$ & $\%$ \\
\hline Distance per day $\left(10^{6} \mathrm{~km}\right)$ & 29,200 & 59 & 20,200 & 41 & 10,900 & 22 & 38,500 & 78 & 49,400 & 100 \\
\hline Number of commuters $\left(10^{3}\right)$ & 892 & 66 & 462 & 34 & 618 & 46 & 736 & 54 & 1354 & 100 \\
\hline
\end{tabular}

meet it. Actually, the most important sub-matrix of $\mathbf{D}$ is $\mathbf{D}^{3}$, as the final demand consists of products, and the GVAs, as well as the employment impacts that are generated by the industries.

In this paper, we do not proceed in the most usual way by analyzing the impact of a change in $\mathbf{y}$ on the output $\mathbf{x}^{\mathbf{I}}$ provided by $\mathbf{D}^{3}$. Our approach consists of modifying matrix $\mathbf{C}$, specifically the sub-matrix B, in the part relating to the consumption by 'under $65^{\prime}$ households. As the total consumption is kept stable, the change in consumption of commuting-related products is offset by a proportional change in the consumption of products which are not related to commuting (and therefore the sum of the total direct effects is zero). Hence, we assume that the marginal propensity to consume (and to save) remains stable. $\mathbf{D}^{\mathbf{3}}$ was then recalculated with the modified $\mathbf{B}$ and $\mathbf{C}$ matrices, which allow the estimation of the new output $\mathbf{x}$ for the same total final exogenous demand $\mathbf{y}$.

With the new output $\mathbf{x}$ and the energy-environmental satellite account, we estimated the new primary energy requirements by industry and by households, as well as the relevant $\mathrm{CO}_{2}$ emissions. In economic terms, the new output also prompts changes in other macroeconomic indicators such as GDP, GVA, VAT, other taxes on products less subsidies, imports and employment.

\section{Results and discussion}

In this section we present some of the most significant opportunity costs relating to the estimated economic, social, energy and environmental impacts associated with intermunicipality commuting.

Following the application of the procedures described in Section 3, we estimated the number of kilometers and the number of inter-municipal commuters for the three scenarios (Table 2).

These figures were then used to model the scenarios in the Input-output framework. The results are presented in Tables 3 and 4. The differentiation assumed between the analyzed scenarios may help to provide a more detailed picture of the various opportunity costs arising from the spatial distribution of commuting and the type of such commuting.

The results regarding primary energy consumption and $\mathrm{CO}_{2}$ emissions $^{3}$, in Table 3 , are representative of the negative impact on the environment of the opportunity costs of commuting.

According to these results, metropolitan and long commuting are the main factors responsible for primary energy consumption and thus for the $\mathrm{CO}_{2}$ emissions associated with inter-municipality commuting. In the hypothetical situation where metropolitan inter-municipality commuting ceases, the impacts would be a $2.5 \%$ decrease in the consumption of Oil and its derivatives, while the cessation of commuting in the rest of Portugal would only decrease the consumption of this type of primary energy by $1.5 \%$. The effects in terms of $\mathrm{CO}_{2}$ emissions are also more substantial

\footnotetext{
${ }^{3}$ The $\mathrm{CO}_{2}$ emission values in Table 3 differ from the ones provided by the IPCC data on National GHG Inventories as the latter do not include the primary energy consumption associated with exports.
} 
Table 3

Energy and environmental impacts of commuting.

\begin{tabular}{|c|c|c|c|c|c|c|c|c|c|c|c|}
\hline & \multirow{3}{*}{$\begin{array}{l}\text { Initial value for } \\
\text { Portugal }\end{array}$} & \multicolumn{4}{|c|}{ Scenario 1} & \multicolumn{4}{|c|}{ Scenario 2} & \multicolumn{2}{|c|}{ Extreme scenario } \\
\hline & & \multicolumn{2}{|c|}{ Metropolitan } & \multicolumn{2}{|c|}{ Non-metropolitan } & \multicolumn{2}{|l|}{ Short } & \multicolumn{2}{|l|}{ Long } & & \\
\hline & & $\begin{array}{l}\text { Absolute } \\
\text { change }\end{array}$ & $\begin{array}{l}\% \\
\text { change }\end{array}$ & $\begin{array}{l}\text { Absolute } \\
\text { change }\end{array}$ & $\begin{array}{l}\% \\
\text { change }\end{array}$ & $\begin{array}{l}\text { Absolute } \\
\text { change }\end{array}$ & $\begin{array}{l}\% \\
\text { change }\end{array}$ & $\begin{array}{l}\text { Absolute } \\
\text { change }\end{array}$ & $\begin{array}{l}\% \\
\text { change }\end{array}$ & $\begin{array}{l}\text { Absolute } \\
\text { change }\end{array}$ & $\begin{array}{l}\% \\
\text { change }\end{array}$ \\
\hline $\begin{array}{l}\text { Oil and derivat. } \\
\left(10^{3} \text { toe }\right)\end{array}$ & 15,653 & -393 & -2.5 & -225 & -1.5 & -115 & -0.7 & -503 & -3.3 & -618 & -4.0 \\
\hline Natural gas $\left(10^{3}\right.$ toe $)$ & 3773 & 28 & 0.6 & 28 & 0.6 & 15 & 0.4 & 31 & 0.8 & 46 & 1.2 \\
\hline Coal $\left(10^{3}\right.$ toe $)$ & 2910 & 29 & 0.8 & 29 & 0.8 & 15 & 0.5 & 33 & 1.1 & 48 & 1.6 \\
\hline $\begin{array}{l}\text { Total primary energy } \\
\quad\left(10^{3} \text { toe }\right)\end{array}$ & 22,336 & -336 & -1.5 & -188 & -0.9 & -80 & -0.4 & -459 & -2.1 & -524 & -2.4 \\
\hline $\begin{array}{l}\mathrm{CO}_{2} \text { emissions } \\
\left(10^{3} \text { tones }\right)\end{array}$ & 61,521 & -874 & -1.4 & -486 & -0.8 & -216 & -0.3 & 1144 & -1.9 & -1360 & -2.2 \\
\hline
\end{tabular}

Table 4

Economic and social impacts of commuting.

\begin{tabular}{|c|c|c|c|c|c|c|c|c|c|c|c|}
\hline & \multirow{3}{*}{$\begin{array}{l}\text { Initial value for } \\
\text { Portugal }\end{array}$} & \multicolumn{4}{|c|}{ Scenario 1} & \multicolumn{4}{|c|}{ Scenario 2} & \multicolumn{2}{|c|}{ Extreme scenario } \\
\hline & & \multicolumn{2}{|c|}{ Metropolitan } & \multicolumn{2}{|c|}{ Non-metropolitan } & \multicolumn{2}{|l|}{ Short } & \multicolumn{2}{|l|}{ Long } & & \\
\hline & & $\begin{array}{l}\text { Absolute } \\
\text { change }\end{array}$ & $\begin{array}{l}\% \\
\text { change }\end{array}$ & $\begin{array}{l}\text { Absolute } \\
\text { change }\end{array}$ & $\begin{array}{l}\% \\
\text { change }\end{array}$ & $\begin{array}{l}\text { Absolute } \\
\text { change }\end{array}$ & $\begin{array}{l}\% \\
\text { change }\end{array}$ & $\begin{array}{l}\text { Absolute } \\
\text { change }\end{array}$ & $\begin{array}{l}\% \\
\text { change }\end{array}$ & $\begin{array}{l}\text { Absolute } \\
\text { change }\end{array}$ & $\begin{array}{l}\% \\
\text { change }\end{array}$ \\
\hline GVA ( $10^{6}$ Euros $)$ & 14,5698 & 802 & 0.6 & 505 & 0.3 & 424 & 0.3 & 883 & 0.6 & 1307 & 0.9 \\
\hline Imports ( $10^{6}$ Euros) & 66,867 & -47 & -0.1 & -49 & -0.1 & -19 & -0.0 & -77 & -0.1 & -96 & -0.1 \\
\hline $\begin{array}{l}\text { Taxes - Subsid. (excl. VAT). } \\
\quad\left(10^{6} \text { Euros }\right)\end{array}$ & 8549 & -222 & -2.6 & -135 & -1.6 & -110 & -1.3 & -247 & -2.9 & -357 & -4.2 \\
\hline VAT $\left(10^{6}\right.$ Euros $)$ & 14,333 & -62 & -0.4 & -30 & -0.2 & -39 & -0.2 & -53 & -0.4 & -92 & -0.6 \\
\hline GDP (10 6 Euros $)$ & 16,7714 & 515 & 0.3 & 341 & 0.2 & 270 & 0.2 & 586 & 0.3 & 856 & 0.5 \\
\hline $\begin{array}{l}\text { Employment ( } 10^{6} \text { Full-time } \\
\text { eq.) }\end{array}$ & 4986 & 22 & 0.5 & 10 & 0.2 & 14 & 0.3 & 18 & 0.4 & 32 & 0.7 \\
\hline
\end{tabular}

when we analyze the scenario without metropolitan intermunicipality commuting. Additionally, ceasing short distance commuting in Portugal would also have a modest impact on primary energy consumption and $\mathrm{CO}_{2}$ emissions. These results show that ending long distance commuting could help to reduce the consumption of oil and its derivatives by more than $3 \%$ and reduce $\mathrm{CO}_{2}$ emissions by almost $2 \%$. These results are in accordance with Modarres (2013), i.e. a spatial-based policy assigning higher reduction targets for metropolitan and/or long distance commuting offers significant opportunities to more effective commuting policies.

It should be noted that even in the extreme scenario the reduction in the consumption of Oil and its derivatives is smaller than the initial shock. Actually, as the economy grows (because of the increased consumption of other products) the indirect and induced effects are responsible both for a total impact that is lower than the initial reduction and for the increased consumption of natural gas and coal. The substitution of imported products by domestically produced ones leads to a subsequent increase in the consumption of primary energy or electricity. As an example, the higher output of the industry "Production, transport and distribution of electricity" implies an increase of $1.7 \%$ in the consumption of Oil and its derivatives. The $\mathrm{CO}_{2}$ emissions would also fall significantly, mainly because of the declining consumption of fuels and refined petroleum products.

Table 4 gives the estimated changes in the main socioeconomic variables for each of the scenarios considered.

The indirect and induced estimated effects are positive in that they indicate an expected increase in the GDP, GVA and employment for each of the scenarios considered. With particular policy relevance, this reveals that targeting interventions at metropolitan and long commuting is associated with improved results.
Regarding Scenario 1 and the spatial distribution of intermunicipality commuting, it is important to highlight that metropolitan commuting has larger opportunity costs (in the variables: taxes and VAT, GVA, GDP and employment) than nonmetropolitan commuting. In terms of imports the results are similar for both the metropolitan and non-metropolitan dimensions. In the second scenario, the effects of weakening short distance inter-municipality commuting are more modest than those concerning long commuting. This is mainly due to the higher relative use of fuel in long commuting. It is also important to mention that in terms of employment the difference between short and long commuting is less significant. Thus, while "who" commutes is relevant for understanding the impacts, "where" and "how" these journeys take place are also critical for an appropriate assessment of the energy, environmental and socio-economic implications.

Significantly, in the most extreme scenario, with no intermunicipality commuting, 116 of the 125 industries included in the I/O model would increase their output and overall the Portuguese GVA would increase by approximately $0.9 \%$. The estimations found that the industries that increase more in terms of GVA are Other passenger land transport, Telecommunications, Real estate activities and Retail trade, except in motor vehicles and motorcycles. Among the most negatively affected industries are the Manufacture of refined petroleum products, the Food and beverage service activities, Wholesale, Retail trade and Repair of motor vehicles and motorcycles and Warehousing and support activities for transportation.

For all the scenarios, the overall impact on imports is mitigated $(-0.1 \%)$ since the initial shock is mainly offset by the effect of the increase in household income and consequently in private consumption (induced effect). Another interesting result concerns the 
estimated reduction in Other taxes on products and VAT. Accordingly, the increased consumption of the majority of the products and thus on the associated Other taxes on products and VAT, should not offset the reduction in the consumption of products with relatively high rates of Other taxes and VAT, as is the case of motor vehicles and petroleum products.

Finally, in terms of net employment effects, the changes in household consumption for all the scenarios would result in a positive impact. In terms of industries, the majority of the employment generated would be associated with Agriculture and livestock rearing, the Retail trade (except in motor vehicles and motorcycles) and the Other land passenger transport industries. Summing up, in the case of the most extreme scenario, if households' consumption is reallocated from products associated with commuting to the other products it is expected that the economy grows and the consumption of primary energy inputs decreases. So, according to the results obtained, Portuguese GDP would increase $0.5 \%$ and employment $0.7 \%$. Additionally, savings in terms of the use of oil and derivatives would be more than $3 \%$ and the reduction in $\mathrm{CO}_{2}$ emissions could exceed $2 \%$.

\section{Conclusion}

The main purpose of the research was to assess the relative magnitude of the economic, social, energy and environmental opportunity costs from commuting in order to assist policy making.

Our results show that, in Portugal, inter-municipality commuting is responsible for significant impacts on the overall consumption of oil and derivatives and on the relevant $\mathrm{CO}_{2}$ emissions. According to Scenarios 1 and 2, it is possible to conclude that the main responsibility for commuting-derived energy consumption and emissions is largely attributable to metropolitan and long inter-municipality commuting.

Our research results also suggest that the absence of urban and energy policies to counteract the growing increase of the distances traveled by commuters (e.g., by controlling urban sprawl), is, in addition to the negative impacts on primary energy consumption and $\mathrm{CO}_{2}$ emissions, contributing to an important contractionary impact on the economy. Furthermore, city and regional development based on the use of private transport imposes a significant supplementary macroeconomic burden on economies where oil (and/or its derivatives) and cars are mainly imported. Under these circumstances, one may argue that a lose-lose situation may emerge in which neither the environment nor the economy can benefit in the absence of a more restrictive regulation that considers these opportunity costs.

These research conclusions empirically support policy-oriented measures capable of reducing car use, restraining commuting intensity and the amount of kilometers traveled every day by metropolitan residents, because such measures are potentially beneficial to macroeconomic indicators such as GDP, GVA and employment. These suggestions have the additional significance that for economies where oil and its derivatives are predominantly imported such policy measures would positively contribute to socio-economic growth and also improve the three pillars of energy policy: security of supply, competitiveness and environmental protection.

The potential policy alternatives can focus on transportation policies, land-use policies and even on labor policies. In the first case, several TDM strategies, which are still scarcely applied at all in Portugal, could represent an important input for a more sustainable future with respect to inter-municipality commuting. Land-use policies, on the other hand, have the potential to better reflect the social costs of living in the suburbs through the private costs supported by suburban residents. Additionally, labor market policies may also include differentiated labor taxes applied to the work force or to companies, taking into account the distance traveled, the vehicle used or the overall distance traveled by each employee. To sum up, besides all the negative effects that have been widely set out in reports, academic papers and legislative documents, the inter-municipality commuting status quo has also been contributing to high economic opportunity costs that continue to be almost wholly ignored by local and national governments. In many cases, even if some of these costs are invisible, their economic, social and environmental consequences are definitely quite noticeable.

\section{Acknowledgments}

This work has been carried out under the Energy for Sustainability Initiative of the University of Coimbra and supported by the R\&D Project EMSURE - Energy and Mobility for Sustainable Regions (CENTRO-07-0224-FEDER-002004) and by Fundação para a Ciência e a Tecnologia (FCT) under PhD Grant FCT-DFRH-SFRH/BD/ 76357/2011 and project FCT-PTDC/CS-DEM/100530/2008.

\section{References}

ACAP, 2009. Estatísticas do Sector Automóvel de 2010. Lisboa, Portugal. 〈http://www.autoinforma.pt/estatisticas/estatisticas.html?MIT=36458〉 (accessed 02.01.12).

Alcántara, V., Roca, J., 1995. Energy and $\mathrm{CO}_{2}$ emissions in Spain: methodology of analysis and some results for 1980-90. Energy Eco. 17 (3), 221-230.

Alcántara, V., 2011. Determinant sectors of $\mathrm{CO}_{2}$ emissions in Spain: an input-output analysis approach. In: Llop, M. (Ed.), Air Pollution: Economic Modelling and Control Policies, Universita Rovira I Virgili. Bentham Science Publishers Ltd., Barcelona, Spain, pp. 1-12.

Balat, M., Balat, H., 2009. Recent trends in global production and utilization of bioethanol fuel. Appl. Energy 86 (11), 2273-2282.

Banister, D., Watson, S., Wood, C., 1997. Sustainable cities: transport, energy an urban form. Environ. Plann. B: Plann. Des. 24 (1), 125-143.

Barata, E., Cruz, L., Ferreira, J., 2011. Parking at the UC: problems and solutions. Cities 28 (5), 406-413.

Berglund, M.,2012. The global climate impact of Swedish consumption: an inputoutput analysis time series of $\mathrm{CO}_{2}$ emissions from 1993 to 2005. In: Proceedings of the 20th International Input-output Association Conference, Bratislava, Slovakia.

Brueckner, J., 2000. Urban sprawl: diagnosis and remedies. Int. Reg. Sci. Rev. 23 (2), $160-171$.

Carvalho, J., D'Abreu, A., Pais, C., Gomes, P., 2012. Ocupação Dispersa: Custos e benefícios à escala local. Universidade de Aveiro, Portugal.

Cruz, L., Proops, J., Safanov, P., 2005. Input-output models. In: Proops, J., Safanov, P. (Eds.), Modelling in Ecological Economics. Edward Elgar Publishing, Cheltenham-UK, pp. 36-57. (Chapter 3).

Cruz, L., 2009. Application of $\mathrm{IO}$ energy analysis for $\mathrm{CO}_{2}$ emissions by the Portuguese economy. In: Suh, S. (Ed.), Handbook of Input-Output Economics in Industrial Ecology, Eco-Efficiency in Industry and Science, 23. Springer, pp. 507-532, http://dx.doi.org/10.1007/978-1-4020-5737-3_25.

Cruz, L., Barata, E., 2011. Hybrid IO analysis of $\mathrm{CO}_{2}$ emissions: an application to the Portuguese economy. In: Llop, M. (Ed.), Air Pollution: Economic Modelling and Control Policies. Environmental Sciences Series, Bentham EBooks, pp. 65-96. (Chapter 5), http://dx.doi.org/10.2174/978160805217211101010065.

Camagni, R. Gibelli, M. Rigamonti, P. 2002. Urban mobility and urban form: the social and environmental costs of different patterns of urban expansion. Ecol. Eco. 40, 199-216.

Cardenete, A. Saguar, P. 2011. Eneroy consumption and $\mathrm{CO}_{2}$ emissions in the Spanish economy. In: Llop, M. (Ed.), Air Pollution: Economic Modelling and Control Policies, Universita Rovira I Virgili. Bentham Science Publishers Ltd., Barcelona, Spain, pp. 46-64

D'Acierno, L., Gallo, M., Montella, B., 2006. Optimisation models for the urban parking pricing problem. Transp. Policy 13 (1), 34-48.

DGEG, 2012a. Estatísticas - Balanços Energéticos 2007, Lisbon, Portugal.

DGEG, 2012b. Evolução dos Preços da Gasolina em Portugal Continental 2004 a 2012. Lisbon, Portugal. 〈http://www.dgge.pt〉 (accessed 07.01.12).

Dils, E., Vercalsteren A., Linden A., Geerken T., 2012. Sustainable production and consumption of food in Flanders. In: Proceedings of the 20th International Input-Output Association Conference, Bratislava, Slovakia.

Dorsey, B., 2005. Mass transit trends and the role of unlimited access in transportation demand management. J. Transp. Geogr. 13 (3), 235-246.

EUROSTAT, 2013. Environment and Energy Indicators, European Comission. 〈http://epp. eurostat.ec.europa.eu/portal/page/portal/statistics/themes (accessed 08.01.13). 
8

J.-P. Ferreira et al. / Energy Policy

Ferreira, J.-P., Pina, R., Ramos, P., 2012. Distâncias e Acessibilidades na Região Centro e no Continente Português, Boletim Trimestral, n ${ }^{\circ} 15$. CCDRC, Coimbra, Portugal.

Frank, L., Pivo, G., 1994. Impacts of mixed use and density on utilization of three modes of travel: single-occupant vehicle, transit, and walking. Transp. Res. Rec. 1466, 44-52.

Eu, M., Kelly, J., Clinch, J., King, F., 2012. Environmental policy implications of working from home: modelling the impacts of land-use, infrastructure and socio-demographics. Energy Policy 47, 416-423.

Glaser, E., Kahn M., 2001. Decentralized Employment and the Transformation of the American City. NBER Working Paper, 8117.

IA, 2011. Portuguese National Inventory Report on Greenhouse Gases, 1990-2009, Submitted under the UNFCCC, Institute do Ambiente, Amadora.

IEA, 2006. World Energy Outlook. International Energy Agency, Paris.

INE, 2003. Censos - Resultados Definitivos. Lisboa, Portugal.

INE, 2008. Inquérito às Despesas dos Famílias (2005-2006). Lisbon, Portugal.

INE, 2011. Contras Nacionais Anubis Definitivas 2007 (Base 2000). Lisboa, Portugal. INE, 2012. Censos - Resultados Provisórios. Lisboa, Portugal.

IPCC, 2006. 2006 IPCC Guidelines for National Greenhouse Gas Inventories, Prepared by the National Greenhouse Inventory Programme, Eggleston, H.S. Buendia, L., Miwa, K., Ngara, T., Tanabe, K. (Eds.), IGES, Japan.

Labandeira, X., Labeaga, J., 2002. Estimation and control of Spanish energy-related $\mathrm{CO}_{2}$ emissions: an input-output approach. Energy Policy 30 (7), 597-611.

Litman, T., 2011. Evaluating Public Transit Benefits and Costs. Victoria Transport Policy Institute. Available from: 〈www.vtpi.org/tranben.pdf (accessed 12.07.13).

Meyer, M., 1997. A Toolbox for Alleviating Traffic Congestion and Enhancing Mobility. Institute of Transportation Engineers, Washington D.C.

Meyer, M., 1999. Demand management as an element of transportation policy: using carrots and sticks to influence travel behaviour. Transp. Res. A 33, 575-599.

Miller, R., Blair, P., 2009. Input-Output Analysis: Foundations and Extensions. Cambridge University Press, Cambridge, UK.

Modarres, A., 2013. Commuting and energy consumption: toward an equitable transportation policy. J. Transp. Geogr. 33, 240-249, http://dx.doi.org/10.1016/j. jtrangeo.2013.09.005.
Muñiz, I., Gallindo, A., 2005. Urban form and the ecological footprint of commuting: the case of Barcelona. Ecol. Eco. 55, 499-514.

Murray, A., 2001. Strategic analysis of public transport coverage. Socio-Economic Planning Sciences 35 (3), 175-188.

Ness, P., 2010. Residential location, travel and energy use: the case of Hangzhou Metropolitan Area. J. Transp. Land Use 3, 27-59.

Næss, P., Røe, P., Larsen, S., 1995. Travelling distances, modal split and transportaton energy in thirty residential areas in Oslo. J. Environ. Pan. Manage. 38 (3), 349-370.

Offer, G., Howey, D., Contestable, M., Claque, R., Brandon, N., 2010. Comparative analysis of battery electric, hydrogen fuel cell and hybrid vehicles in a future sustainable road transport system. Energy Policy 38 (1), 24-29.

Ot, X., Chang, X., Chang, S., 2010. Scenario analysis on alternative fuel/vehicle for China's future road transport: life-cycle energy demand and GHG emissions. Energy Policy 38 (8), 3943-3956.

Ramos, P., Cruz, L., Castro, E., 2011. Economically Sustainable Demography: Reversing Decline in Portuguese Peripheral Regions. Proceedings of the 19th International Input-Output Association (IIOA) Conference, 13-17 June, Alexandria, Virginia, USA (http://www.iioa.org/conferences/19th/papers/files/ 397_20110429061_Ramos_Castro_Cruz_IIOA_USA_397.pdf).

Shimpo, K., Older, A., Ganju, K., Madam, P., Singh, J., Mather, R., 2009. Mitigating $\mathrm{CO}_{2}$ emissions of rural households in India: input-output analysis of LABL (Lighting a Billion Lives). In: Proceedings of the 17th International Input-Output Association Conference, São Paulo, Brazil.

Susilo,Y., Stead, D., 2007. Urban form, vehicle emissions and energy use of commuters in the Netherlands. In: Proceedings of ECEEE 2007 Summer Study, Saving Energy - Just do it, 1595-1604. La Colle sur Loup, France.

Thill, C., Perujo, A., Mercier, A., 2010. Cost and $\mathrm{CO}_{2}$ aspects of future vehicle options in Europe under new energy policy scenarios. Energy Policy 38 (11), 7142-7151. Tisato, P., 1998. Service unreliability and bus subsidy. Transp. Res. A 32 (6), $423-436$.

Zhao, P., Lu, B., Roo, G., 2011. The impact of urban growth on commuting patterns in a restructuring city: evidence from Beijing. Pap. Reg. Sci. 90 (4), 735-754.

Please cite this article as: Ferreira, J.-P., et al., Economic, social, energy and environmental assessment of inter-municipality commuting:

The case of Portugal. Energy Policy (2013), http://dx.doi.org/10.1016/j.enpol.2013.11.010 